Draft Last Edited: March 2010

\title{
Persistence of women and minorities in STEM field majors: Is it the school that matters?
}

\author{
Amanda L. Griffith \\ Wake Forest University \\ Department of Economics \\ Box 7505 \\ Winston-Salem, NC 27109 \\ Email: griffial@wfu.edu
}

\begin{abstract}
During college, many students switch from their planned major to another, particularly so when that planned major was in a Science, Technology, Engineering, or Mathematics (STEM) field. A worrying statistic shows that persistence in one of these majors is much lower for women and minorities, suggesting that this may be a leaky joint in the STEM pipeline for these two groups of students. This paper uses restricted-use data from the National Longitudinal Survey of Freshmen (NLSF) and the National Education Longitudinal Study of 1988 (NELS:88) to examine which factors contribute to persistence of all students in STEM field majors, and in particular the persistence of women and minorities. Although descriptive statistics show that a smaller percentage of women and minorities persist in a STEM field major as compared to male and nonminority students, regression analysis shows that differences in preparation and the educational experiences of these students explains much of the differences in persistence rates. Students at selective institutions with a large graduate to undergraduate student ratio and that devote a significant amount of spending to research have lower rates of persistence in STEM fields. A higher percentage of female STEM field graduate students positively impacts on the persistence of female students. However, there is little evidence that having a larger percentage of STEM field faculty members that are female increases the likelihood of persistence for women in STEM majors. These results suggest that the sorting of women and minorities into different types of undergraduate programs, as well as differences in their backgrounds have a significant impact on persistence rates.
\end{abstract}

Acknowledgements: I would like to thank Ronald Ehrenberg, Kevin Rask and Joshua Price for their helpful comments. I would also like to thank Yi Qian and Basit Zafar for their assistance with data, and Tom Eisenberg for able research assistance. 


\section{Introduction}

Many students enter college with an intended major in mind, only to change partway through their college careers. For students entering college as a Science, Technology, Engineering, or Mathematics (STEM) major this is especially the case. Women and minorities are even less likely to persist in a STEM field major during college than are male and non-minority students (National Science Board, 2007). As many feel that a strong STEM workforce is important for future development, it is essential to understand the reasons for under-representations of certain groups within this workforce. Over the last few decades, representation of women and minorities in STEM fields post-college has increased, but gaps still remain (NCES, 2006). Much of this may be due to supply - there are fewer women and minorities receiving bachelor's degrees in STEM fields. This is for two reasons: both groups are less likely to pick a STEM major initially, and if they do, less likely to remain in that major (NCES, 2009).

In response, many interested in the advancement of science have issued reports or recommendations that increasing the strength of the STEM pipeline should be a core goal. One such report, issued jointly by the National Academy of Science, The National Academy of Engineering, and the Institute of Medicine recommends a focus on improving the post-secondary education portion of the STEM pipeline, with increased teaching resources aimed at increasing the numbers of STEM undergraduate majors (National Academy of Science, 2005). However, it is still not well understood exactly what factors affect persistence in STEM majors during college, and therefore where the focus should be placed in order to improve persistence. 
When students enter college and pick an initial major, they are already entering with differing educational backgrounds - how much does this play a role in their initial choices, as well as their ability and desire to persist in a STEM major? As they progress through their college career, students also have different experiences. They take different classes, with different professors and with different peers. If professors of the same gender or race serve an important role as mentors, women and minority students may be at a disadvantage as both groups are also under-represented as faculty members in STEM field departments. Students matriculate at a number of different institutions, where the focus on STEM education may be very different. Some institutions have graduate programs and often graduate teaching assistants in the classroom, and some devote significant funds to scientific research. All of this leads up to very different educational experiences of students in STEM majors at different colleges and universities.

This paper uses longitudinal data on students at a wide-range of four-year institutions to examine how student and institutional characteristics affect the decision to persist in a STEM major. This analysis is followed by an investigation of where students go when they leave a STEM field major, which STEM majors most students leave from, and when they make this choice. Results suggest that institutional characteristics play a key role. Students at institutions with more undergraduate students relative to the number of graduate students are more likely to persist, suggesting that institutions with a focus on undergraduate education are more successful in retaining their undergraduate majors. Along the same lines, students at selective colleges with large research expenditures relative to total educational expenditures have lower persistence rates, particularly minority students. There is little evidence that faculty role models have a large impact on 
persistence rates for women and minorities. However, for schools with STEM graduate students, and presumably graduate teaching assistants, a higher percentage of female graduate students in STEM fields has a positive effect on persistence rates of female students.

These results suggest that the types of institutions that students attend, and their educational experiences at these institutions, have a large impact on their probability of persisting in a STEM major. This paper continues as follows: Section II provides background information on research in this area, Section III introduces the data sets used and provides descriptive statistics. Section IV discusses the results of the study, and Section V concludes.

\section{Background}

Much research has focused on the presence and importance of faculty role models in the major choice decision. The fraction of female and/or minority faculty in STEM departments is very low, so if role models of the same gender or race are important factors in major choice, this could play an important role in the under-representation of women and minorities in STEM field majors. Results that faculty members may serve as

role models are mixed. Some studies suggest that female faculty members do encourage female students to select a major (Carrell, Page \& West, 2010; Rask \& Bailey, 2002; Ashworth \& Evans, 2001). A 1998 paper by Robst and coauthors using University of Binghamton administrative data finds that a higher fraction of female instructors in math and science courses is correlated with increased persistence of female majors in these 
fields. However, a 1995 paper by Canes and Rosen, also using institutional data, finds no link between the percentage of female faculty in a department and the percentage of majors that are female.

Using administrative data from Ohio public universities and accounting for selection into specific courses with specific faculty members, Bettinger and Long (2007) find that female faculty members increase the probability of female students taking additional courses in Math and Geology. However, they find the opposite effect for Biology and Physics courses. Another approach is to examine major choice at the institution level. In a 2009 working paper, Zafar and Qian find that as the percentage of female faculty in STEM departments increases, the percentage of four-year degrees awarded to females in these departments also increases.

Sensitivity to grades received may also be a very important factor in the major choice decision. Rask and Tiefenthaler use administrative data from a Liberal Arts college to investigate how grades received affect a student's decision to continue within the Economics major (2008). They find that lower grades lead to lower persistence, and that this effect is stronger for women. As it is generally true that STEM field departments are the most difficult grading departments at most colleges, this finding could also play a large role in the underrepresentation of women in STEM field majors, and their higher rates of attrition from the major following matriculation.

In general, results from studies focused on persistence in the STEM major during college are very mixed. Past studies have focused on either institution level data, or have used administrative data sets for one or more particular institutions. These data sets have the strength of allowing the researcher the ability to match students with instructors and 
peers. However, they do not allow comparisons of student major choices across different types of institutions. Another possible mechanism through which students may be supported in or discouraged from continuing in a STEM field major is how focused an institution or department is on undergraduate education, and this will differ more across institutions than within. This focus can be measured in a number of ways. Institutions with large graduate school populations may be more interested in research output and the production of $\mathrm{PhDs}$ than in fostering undergraduate learning. However, it is also possible that this type of institution may create a beneficial environment for undergraduate students as there are now additional role models or mentors in the form of graduate students. Institutions that devote a large proportion of their educational budget to research spending may also have less of a focus on undergraduate education, and therefore have lower persistence rates in their STEM field majors, as this is the area where most research spending is done.

This paper uses longitudinal data on students matriculating at a wide range of four-year institutions in order to investigate how student and institutional characteristics affect the decision to remain in a STEM field major. The two data sets used allow a direct analysis of how differing university and college characteristics impact on students' major choices.

\section{Data and Methods}

This paper uses data from two restricted data sources. The first is the National Longitudinal Survey of Freshmen (NLSF). This source, funded by the Andrew Mellon 
Foundation and the Atlantic Philanthropies, first surveyed students entering 28 selective colleges and universities in the U.S. in the fall of 1999. Data were collected on background characteristics such as high school grades and advanced placement courses taken, and the student's intentions for post-secondary study, including their intended major. Follow-up surveys were conducted each spring, collecting data on the courses taken as well as the grades received in each course. In their sophomore and senior years, students were asked to report their current major. The survey was designed to oversample minority student populations, which allows for a detailed analysis here of the major choices of minority students.

The second restricted-use data set used is a National Center of Education Statistics product, the National Education Longitudinal Study of 1988 (NELS:88). This study originally surveyed students in the eighth grade in 1988, with subsequent followups in the tenth and twelfth grades. Data including high school GPA, number and subject of AP courses taken, and the student's intended college major are taken from the second follow-up. These students were then followed through college and transcripts are provided listing all of the courses taken during college, the grades received, and the final major at graduation.

Data on college characteristics are derived from the Integrated Post-Secondary Education Data System (IPEDS). This includes the ratio of undergraduate to graduate students at the institution ${ }^{1}$ and the ratio of expenditures on research to educational expenditures. Both are intended to measure the educational and research focus of an institution. Ideally, to measure the focus on education versus research in STEM field

\footnotetext{
${ }^{1}$ Both enrollment numbers are measured in full-time equivalents. Part-time students are calculated as 1/3 of a full-time student.
} 
departments at each university, one would want just STEM expenditures on the two. However, educational expenditures are available only at the institution level so institution level research expenditures are used as a comparable measure to create the ratio. These correlate quite highly to research expenditures for STEM departments and therefore are a good proxy for the level of research spending in STEM departments at the institution².

A measure of the gender and race composition of the student body is measured as the average of the percentage of STEM undergraduate majors and STEM graduate students that are female or minority students during the student's first two years of college. The percentage of STEM undergraduate majors that are female or minority students is normalized by the percentage of all majors at that institution that are female or minority students, in order to avoid measuring a general trend at that particular university for there to be more or fewer women and minorities. To measure the female faculty members available to serve as possible mentors for undergraduate students interested in STEM one would ideally want the faculty gender composition of the STEM field departments. A higher percentage of faculty members that are female would therefore measure more opportunity for female students to identify with female role models in the field, or to connect with a female mentor in the field. However, data on faculty gender composition by department is not readily available for the years needed here. The most recent year available from IPEDS, 1985, is used as a proxy for faculty gender composition for the NELS:88 sample. The gender composition of STEM field faculty for the schools in the NLSF sample was calculated from current faculty lists at each of the institutions. Assuming that female representation as faculty members in STEM fields has

\footnotetext{
${ }^{2}$ When compared to S\&E expenditures on R\&D as reported by the NSF (webcaspar.nsf.gov), the correlation coefficient of total institutional research expenditures and S\&E R\&D expenditures is 0.98 .
} 
remained the same or more likely increased over the last two decades, the proxy for the NELS:88 sample will likely understate the true faculty gender composition, and the proxy for the NLSF sample will likely overstate female representation. How these measurement issues may affect estimates will be discussed in the results section.

Descriptive statistics for both data sets are shown in Tables 1 and 2. Panel A of Table 1 shows the demographic breakdown of students who report a STEM field as an intended major and those who do not and there are some interesting patterns. Thirtythree percent of the students in the NELS:88 data set planning to major in a STEM field are female, while $62 \%$ of those majoring in a non-STEM field are female. There is a similar, yet much smaller, difference in the proportion of initial STEM and non-STEM majors in the NLSF sample that are female: $51 \%$ versus $60 \%$. There are likely two possible reasons for the big increase in the percentage of initial STEM majors that are female. First, the NELS:88 sample contains students starting post-secondary study at the beginning of the decade (1992), while the NLSF sample looks at students who were freshmen in 1999. This change could be illustrating a trend over this time period for movement toward STEM majors by female students. Additionally, students in the NLSF sample were attending far more selective institutions on average than students in the NELS:88 sample, and it may be that initial major choices are very different across different types of institutions. Most importantly though, both data sets show that at the start of college, women make up a larger percentage of planned non-STEM majors than they do of planned STEM majors and they are less than 50\% of STEM majors, despite making up at least $50 \%$ of the student body at most four-year institutions. For minority students there is not a similar pattern in either dataset. The NLSF reports much larger 
percentages for minority students in both types of fields, but this is due to the design of the study (oversampling of minority populations).

Planned STEM majors tend to have higher high school GPAs on average, and to have taken a larger percentage of their AP courses in STEM fields, than do students that planned to major in a non-STEM field. In the NELS:88 sample there is a large difference in average SAT scores between the two groups of planned majors, but this pattern is not seen with the NLSF sample.

Panel B of Table 1 examines initial major choices and persistence rates by gender and race for both of the data sets. Prior to enrollment in college, students from both samples were asked their intended major. However, many of these students in the NLSF data set responded that they were undecided at that point. To attempt to capture a subset of the students that were actually interested in a STEM major, but did not report it at this stage, a second group is defined as those that either reported they planned to major in a STEM field, or took more than half of their first-year classes in STEM field departments (listed as Freshman STEM). The students that actually reported interest in a STEM major are likely the more dedicated students as they have already identified an interest in one of these subjects. However, the additional students in the second group may be exactly the group of students that we are interested in retaining in a STEM major, as they could be the marginal students that could be influenced to either persist or drop out of the field, given their experiences during college and their backgrounds.

The under-representation of women initially declaring a STEM major is apparent in both samples, particularly so for the NELS:88 sample where 13\% of women initially majored in a STEM field, while 34\% of men did so. The NLSF shows a much smaller, 
but still present differential of 21\% of women planning to major in STEM and 29\% of men. Looking at the expanded planned major sample for the NLSF, this difference widens a bit with $32 \%$ of women showing interest in a STEM field, and $43 \%$ of men doing so. This under-representation continues with persistence rates, which are defined for those that initially planned to major in a STEM field. The NLSF surveys ask for declared major in the sophomore year in addition to the senior year, allowing a snapshot of movement between majors during the college career. Overall, about $48 \%$ of students reporting a plan to major in a STEM field remain as STEM majors by their sophomore year. Between sophomore and senior year, an additional 13\% of the original STEM majors leave for another major. Therefore, much of the movement out of the STEM major occurs in the first two years of college. Just less than $50 \%$ of women persist in their STEM major to the end of their second year, while just over 55\% of men do. Using the expanded planned major sample as the base group both of these statistics fall slightly to $41 \%$ and $50 \%$, but the differential remains, and actually widens a bit. A much smaller percentage of both genders persist to a degree in a STEM field - 37\% of women and $43 \%$ of men - but again there's a difference between genders. The differential in persistence rates by gender is slightly smaller and not statistically significant in the NELS:88 sample, with $43 \%$ of women and $47 \%$ of men persisting to a four-year degree in a STEM field major.

Only a small percentage of students that initially plan to major in a non-STEM field actually switch to a STEM field major, but of those that do, there is also a large gender differential. In the NLSF sample, $10 \%$ of female students switched to a STEM field by the spring of their sophomore year, while $15 \%$ of men had. Similarly for the 
NELS:88 sample, $8 \%$ of female students switched into STEM by their senior year, and almost $13 \%$ of men did.

There are also some notable differences by race. Although similar percentages of minority and non-minority students in the NLSF sample originally choose to major in a STEM field, only $48 \%$ of minority students remain in a STEM major by sophomore spring, as compared to $54 \%$ of non-minority students. This differential becomes even more pronounced when examining persistence to senior year in a STEM field major. Only 31\% of minority students initially planning to major in a STEM field remain by senior year, while $43 \%$ of non-minority students persist to this point. As the NELS:88 study did not oversample minority populations, sample sizes are very small for the minority/non-minority breakdown. However, as shown in Table 1A, persistence rates to the senior year in a STEM field major for the two groups are very similar to what we saw with the NLSF sample. Of students originally planning to major in a STEM field, 32\% of minority students, and $48 \%$ of non-minority students remained in a STEM field major by senior year.

Table 2 separates the planned STEM majors in each data set into those that persisted in a STEM field to either the sophomore year (NLSF) or the senior year (NELS:88), and those that switched to a non-STEM field during those times. Again we can see under-representation of both female and minority students in the group that persists. $48 \%$ of the students in the NLSF sample that stay in a STEM major until at least their sophomore year of college are female, while $54 \%$ of students in that sample that switch to a non-STEM major are female. There's a similar difference for minority 
students with minority students making up $25 \%$ of those that persist, and $30 \%$ of those that do not.

Students remaining in STEM fields and those switching away from them are very similar in terms of previous educational preparation in the NLSF sample, but very different in the NELS:88 sample, and both samples show very different early educational experiences in STEM field classes for those that persist and those that do not. NLSF students that remained in a STEM major until their sophomore year took slightly more AP tests in STEM fields than did non-persisters, as well as more AP courses overall. There is no significant difference in AP courses in STEM fields or overall for the NELS:88 sample, but the average number of each is much lower, reflecting an increased availability over time of AP courses and courses in different fields. Average high school GPAs were nearly identical across the two NLSF sub-samples at 3.76 and 3.73 respectively, but again there were large differences in the NELS:88 samples with averages of 3.48 and 3.1 for persisters and non-persisters. There are also big differences in SAT scores across the two sub-groups. Students in the NLSF sample that persisted in STEM to the sophomore year had average SAT scores of 1320, while students that switched away from STEM had average SAT scores of only $1276^{3}$. There is a similar pattern with the NELS:88 data with an almost 100 point gap between the average SAT scores for the two sub-samples. These statistics suggest the importance of previous educational preparation in persistence to a STEM field major. Students with less of an emphasis on STEM education in high school, as well as lower high school grades and test scores may not be as well prepared for the often highly rigorous STEM field subjects in

\footnotetext{
${ }^{3}$ Student SAT scores in the NELS:88 data set were re-centered to be comparable to SAT scores reported in the NLSF data.
} 
college. Grades may also play a large role in the decision to persist or not. The ratio of grades received in STEM field classes to non-STEM field classes is much higher for students that persist in the field, by about two tenths of a GPA point. Both are less than one, illustrating the high level of difficulty and often tough grading in STEM field departments.

The types of institutions attended by students in the two samples are quite different, illustrated by the descriptive statistics in Table 3. Colleges and universities in the NELS:88 sample have a much larger undergraduate to graduate student ratio and are much more likely to be institutions with no graduate programs at all. Likely as a result, the schools in the NLSF data on average spend a much larger ratio of educational expenditures to research expenditures, $24 \%$ versus 7. The gender and racial make-ups of the STEM departments at institutions in the two samples are also quite different. On average, 52\% of the STEM majors at NLSF institutions are female. When normalized by the percentage of all majors in the institution that are female, this is only $89 \%$, suggesting that women are under-represented in STEM departments as undergraduates by quite a bit. The difference is even larger at NELS:88 institutions with 36\% STEM majors being female, compared to the normalized 67\%. This difference in under-representation between the two samples might reflect differences in institutions and the students attending them, but it might also illustrate a change in major choice over time, with more females tending towards STEM majors at the end of the decade than at the beginning. Average undergraduate minority representation in STEM majors is much more similar across the two data sets. Minority students make up about $10-11 \%$ of the STEM majors, and when this variable is normalized by the overall minority representation of 
undergraduate majors we see that there is under-representation in STEM fields. Women also make up a very small percentage of the PhD students in STEM fields, $37 \%$ at NLSF schools, and only 8\% at NELS:88 schools. Minority students are even less well represented, only 6\% of STEM PhDs at NLSF schools, less than 1\% at NELS:88 schools.

\section{Empirical Methods}

These descriptive statistics illustrate the low persistence rates in STEM field majors during college, particularly so for female and minority students, and the underrepresentation of these students in the majors. In order to examine how these students' educational preparation and college experiences in STEM field departments affect major choice, a number of empirical specifications are estimated. The logit model is used to estimate the probability of persisting in or switching to a STEM field major, as shown in equation one:

(1) $\operatorname{Pr}\left(Y_{i g}=1\right)=\frac{1}{1+e^{-\left(X_{i g} \beta+Z_{i g} \gamma+\varepsilon_{i g}\right)}}$

Where $Y_{\text {ig }}$ is one of the following persistence measures: persistence in STEM until the sophomore spring, persistence in STEM to the fourth year, and switching into a STEM major by second or fourth year of college. This is estimated separately for each group g: male, female, minority, and non-minority. $X_{i}$ is a vector of personal characteristics which includes gender, race, high school type and GPA, SAT scores, the total number of AP tests, as well as the number in STEM fields, and the student's GPA in STEM courses taken in the first year of college relative to GPA in all other courses. $Z_{i}$ contains a vector of institution characteristics which includes the gender ratio of faculty 
in STEM fields, the ratio of undergraduate to graduate students at the institution, the percentage of STEM field majors and graduate students that are female and minority students, and the ratio of expenditures on research to other educational expenditures.

\section{Results}

\section{Persistence in STEM field major}

The end of the sophomore year is the point at which most colleges and universities encourage or require students to officially declare a major field. Therefore students that may be discouraged from their intended major in a STEM field are likely to choose another major by the end of their sophomore year and in fact, much of the attrition by intended STEM field majors occurs within the first two years of college. A smaller percentage then switches away from STEM field majors between their sophomore and senior years. Table 4 reports average marginal effects from logit estimation results of the probability of persisting in a STEM field major until the spring of the sophomore year, as well as to a degree in a STEM field major, using the NLSF sample. The model is estimated separately by gender, and also by minority status to examine differential impacts of the variables on the different groups. Although women and minorities have lower average persistence rates in a STEM major than men and nonminorities respectively, this difference disappears, or is reversed once controlling for background and institutional characteristics. Minority men are slightly more likely to persist than non-minority men by about 11 percentage points. Taking more AP classes 
in STEM fields, holding total number of APs taken constant, has a positive impact on persistence rates for women and minorities (with a slight impact on persistence to the senior year for male students). The marginal effect is much stronger for minority students than for female students, at 14 percentage points and 4 percentage points respectively. This indicates the importance of prior preparation in STEM fields for probability of persisting in the major, particularly for minority students who may not have as high a level of access to a wide range of STEM APs prior to college.

Student experiences during their first two years seem to have the most significant impact on their decision to persist. Students in all four groups are more likely to remain in a STEM field major as the ratio of their grades earned in STEM courses to grades earned in non-STEM courses increases. This effect seems to be slightly stronger for male and non-minority students, and decreases in impact on probability of persistence in a STEM major to senior year for all groups. The effect of a 10 percentage point increase in the ratio of GPA in STEM courses to all courses (say from 0.8 to 0.9 ) on the probability of persisting in STEM to sophomore year ranges from 3.6 percentage points for minority and female students to 5.6 percentage points for male and non-minority students. It seems that low grades may have a strong impact on all students early on, influencing them to leave a STEM major early in their college career. This finding is similar to that of Rask and Tiefenthaler for Economics majors, except here there is no evidence that women are more sensitive to grades than men.

Institution characteristics also play a significant role in the choice to persist in the major. All four groups are more likely to remain in a STEM field major at institutions with more undergraduate relative to graduate students, as well as at institutions with no 
graduate programs at all. Institutions with very few graduate students relative to the total undergraduate student population are likely to focus more on undergraduate education, which may create a more welcoming environment for these students. Along similar lines, male and minority students at institutions that devote a larger percentage of their spending to research relative to educational expenses are less likely to remain in a STEM field major. For a one standard deviation increase in the research expenditures to educational expenditure ratio there is an 8 percentage point decrease in the probability of persistence in STEM to the sophomore year for male and minority students. There is also a small effect for non-minority students, about half this size. Positive variation in this variable comes from two sources, either an increase in research spending or a decrease in educational spending. Either way, the variation suggests a move more towards research and away from a strict educational expenditure focus. Institutions spending more on research could provide more opportunities for undergraduate students to be involved in research projects with faculty members, something that could build more connection to the field. However, high levels of spending on research relative to education may indicate an institution that is focused more on research, and less on teaching, which could negatively impact students' persistence rates in STEM. For male and minority students, the latter story seems to fit, as students from these two groups at institutions with a high research to educational spending ratio are less likely to remain in a STEM field major.

The gender composition of the department, both the students and the faculty, can impact on persistence decisions. Results in Table 4 show that as the percentage of female faculty in STEM field departments increases, the persistence rates of all but minority students falls. This at first seems like a very strong finding. However, these estimations 
do not control for the rank of the faculty members in the department, and it is likely that many of the female faculty members are at the rank of assistant or associate, as opposed to full professors. So this effect may not be capturing the effect of female faculty members per se, but instead the presence of junior faculty members. Additionally, the data on faculty gender composition for the NLSF sample was collected 10 years after the students had matriculated in the departments and were making their decisions to persist in STEM or not. If one assumes that departments are becoming more female over time then a measure showing that a department has a high percentage of female faculty now would have been more male then. If we assume also that the female faculty role model hypothesis is true, then the effect we find would be biased downwards. However, we might still expect to see differences in effects of faculty gender composition across gender of the student, but when one compares the effect of the faculty gender composition on female and male students' persistence decisions, the effect is very similar albeit slightly less negative for female students, suggesting that there is little evidence here for the faculty role model hypothesis. Female graduate students may serve as role models though. Students attending universities with a larger percentage of the STEM $\mathrm{PhD}$ students that are female are more likely to persist in a STEM field major. A ten percentage point increase in the fraction of STEM PhD students that are female would increase persistence rates of female students by about 7 percentage points. The racial composition of the students in the department seems to have no significant effect on the persistence decisions of minority students.

Table 5 examines persistence from an intended major freshman year in a STEM field to a four-year degree in a STEM field using the NELS:88 sample. This sample 
contains a much wider range of both students and institutions in terms of selectivity, and also examines persistence patterns further in the past. Therefore, there are two reasons why results might differ between the two samples, changing trends, and selection of students into different types of colleges and universities. However, the results look very similar to those in Table 4, with only a few notable exceptions. There are now race or gender impacts, after controlling for background characteristics. Additional AP courses taken in STEM fields has a positive impact on persistence rates of non-minority students (about 9 percentage points per additional course), but no statistically significant impact for any of the other groups. This sample has very few students taking APs in STEM courses, so it might be that there is not enough variation in this measure to capture any impact for the other groups.

Although first year performance in STEM courses relative to overall performance is still a very good predictor of persistence in STEM, there are some differences in the strength of the effect across the two samples. There seems to be no difference in sensitive to grades across the groups, and all four groups seem to be less sensitive to grades than we saw in the NLSF sample. For example, female students in the NELS:88 sample are 2 percentage points more likely to persist in a STEM major as the ratio of STEM grades to all grades increases by 10 percentage points. This is in contrast to a 4 percentage point increase in probability of persistence for the same grade ratio increase in the NLSF sample. It might be that there has been differential grade inflation across departments between the time periods of the two samples. If grading has become more strict in the STEM departments over time, but remained similar (or at least hasn't 
increased at the same rate) in non-STEM departments, it is likely we would see a stronger impact on persistence rates.

The ratio of undergraduate to graduate enrollment does not have a statistically significant effect on persistence decisions for students in the NELS:88 data set. Male students at institutions with no graduate students are less likely to persist than are male students at institutions with graduate programs, the opposite of what we found for the NLSF. This might be an artifact of the different types of institutions in the two samples; the NLSF institutions with no graduate programs are still quite elite institutions, while the average NELS:88 institution without a graduate program is likely quite a bit less selective, and therefore maybe not any more focused on undergraduate education per se than those with graduate programs in the sample. There is also a very different effect of research expenditures than we found in Table 4. There is no effect of research expenditures relative to education expenditures on male students, but there are positive impacts on persistence decisions for the other three groups. Many of the institutions in this sample do not have graduate programs, and for those that do, they are much smaller programs. This might create the opportunity for undergraduate students to be involved with research with faculty, and encourage them to stay in a STEM field major.

Gender composition of the department, both students and faculty, has some different effects on this persistence decision, both from the previous results and between samples. There is no longer any impact of female faculty members on persistence decisions. Remember, this measure is from an earlier year, and therefore likely understates the true female faculty representation in the STEM departments. This measurement error could be biasing the estimate towards zero. The percentage of STEM 
$\mathrm{PhD}$ students that are female no longer has a significant impact on female students, but does have a negative impact on persistence rates of male students.

Many students indicated they were unsure of their intended major, or left the field blank when asked before the start of their freshman year of college. In order to attempt to capture the subset of these students that were very interested in a STEM field major to begin with but ultimately did not choose this major, persistence estimations were also run on the sample of students that either reported their intention to major in a STEM field, or took at least half of their first-year classes in STEM field departments. The results of these estimations are very similar. The importance of graduate student role models becomes significant for minority students, and more significant for female students. A ten percentage point increase in the fraction of STEM PhD students that are female or minorities increases the persistence rates of female students by 11 percentage points, and those of minority students by about 5 percentage points. These results using the expanded sample highlight the importance of having more students "like you" further along in the STEM pipeline.

\section{Switching to a STEM field major}

A very small percentage of students switch into a STEM field major during college, as was seen in Table 1, and there are gender and race differences in who these students are. Table 6 displays average marginal effects from logit estimations of the probability of switching into a STEM field major by the sophomore year or senior year for the NLSF and NELS:88 samples respectively. After controlling for background 
characteristics, female non-minority students are less likely to switch into STEM than male students in the NLSF sample, and all female students in the NELS:88 sample are less likely to switch. So although we did not see a gender impact in movement out of STEM fields, there is a gender difference in movement into STEM fields. Good performance in STEM field courses early on in college and more STEM AP classes are good predictors of switching into a STEM major. Similar to the results for leaving a STEM major, high research expenditures have a negative impact on the probability that male students will switch into a STEM major in the NLSF sample, and a positive impact for male and minority students in the NELS:88 sample. The impact of the gender composition of undergraduate and graduate students is very similar to the results for persistence. Female students at institutions with a higher percentage of their STEM PhD students that are female are more likely to switch into a STEM field major. However, if the percentage of STEM field majors that are female is higher, female and male students are less likely to switch into one of these majors in the NLSF sample. The effect is the opposite for the NELS:88 sample - perhaps indicating that in the early 1990's, low representation of women in STEM field majors prompted increases in entry to these majors, but by 1999 representation had increased enough that there is now a crowding out effect occurring.

\section{Where do they come from and where do they go?}

Having shown some of the factors that can influence a student's decision to leave a STEM field major during college, it is interesting to examine what majors students are leaving for, and what STEM field majors they are predominantly leaving from, if any. 
There seems to be very little pattern to the majors in which initial STEM majors in the NLSF sample ultimately end up. However, wherever they do end up, $28 \%$ of them take their first class in that major in their first semester at college. This indicates that many might originally indicate an interest in a STEM field major, but early exposure to departments outside of STEM may influence students to pursue a different major. Most of the students that ultimately switch away from a STEM field major indicated that they originally intended to pursue a major in the life sciences or engineering. For female students leaving a STEM major, 53\% originally indicated an interest in a biological science major. The majority of male students leaving a STEM major come mostly from an engineering major originally (39\%). There is a similar pattern for minority and nonminority students, with $50 \%$ of minority students that are leaving a STEM major starting in biological sciences, and about 35\% of non-minority students leaving biological sciences and engineering each.

Although few students switch into a STEM field major during college, there is a small amount of entry. Of these students, there is fairly equal entry into the four main STEM fields, math/computer science, biological sciences, physical sciences, and engineering, with a slightly smaller percentage entering a physical sciences major. An even smaller percentage, 9.3\%, of students that start in any of the four STEM field majors remains a STEM field major at graduation, but switches between the fields during college. The majority of female and minority students moving between STEM majors are leaving biological science majors and switching into an engineering major. In contrast, the majority of male and non-minority switchers leave engineering for mathematics or computer science. These patterns indicate that there is more to be understood about 
switching out of, into and between STEM field majors by investigating each type of major on its own, as there seems to be differing forces at work. Administrative data sets with much larger sample sizes of students in these majors would be needed for this type of analysis, which could provide further insight into the major choice process.

\section{Conclusion}

The futures of the scientific workforce and advancements in science in the U.S. are contingent on the supply of talented people in these fields. Many students interested in pursuing a science, technology, engineering or mathematics field during their postsecondary career ultimately do not earn a major in one of these fields. This is an important part of the STEM pipeline that is receiving increased attention as of late. In

particular, female and minority students are less likely to enter college intending to major in a STEM field major, but if they do so, are more likely to switch away from a STEM major. Although a few studies have started to investigate the factors leading to these discrepancies, there is still need for further research.

This paper examines how student and institutional factors affect the decision to persist in a STEM field major through college, using two restricted-use data sets: the National Education Longitudinal Study of 1988 (NELS:88) and the National Longitudinal Survey of Freshmen (NLSF). The first allows a general study of major progression for students at a wide range of four-year institutions, while the second allows a more in-depth examination of major choice at more selective institutions, particularly for female and minority students. This study examines how institutional characteristics 
like the gender and racial makeup of the STEM departments' faculty, undergraduates and graduate students, as well as the research and undergraduate teaching focus of the institution as a whole can impact on major choice decisions.

Results show that student experiences during college in STEM field departments can have an important impact on their decision to continue in a STEM major. Higher grades in STEM field courses relative to all other courses in the first year increase the probability of continuing in the major. There is limited evidence that in the selective NLSF sample, male and non-minority students may be slightly more sensitive to their first-year STEM grades in their major choice decision by the end of their sophomore year of college. However, this effect doesn't seem to hold with the NELS:88 sample, a more general sample of students attending four-year colleges in the U.S.

The educational focus of the college or university attended also appears to impact on major choice for students in STEM majors. Students at selective institutions with a higher undergraduate to graduate student ratio are more likely to remain in a STEM field major. The effect of research spending appears to be mixed. Large expenditures on research relative to other educational categories at the selective institutions leads to a decrease in STEM persistence rates, particularly for male and minority students, whereas an increase in research expenditures in the less selective sample of institutions has a positive impact on STEM persistence rates. Taken together with the other characteristics of these institutions, these results suggest that students attending colleges or universities with a focus on teaching and research for undergraduate students are more likely to remain in a STEM field major, while those attending institutions with more emphasis on 
graduate programs (as is the case in many of the selective institutions in the NLSF sample) are much less likely to remain in a STEM field major.

There is some evidence that role models could play a part in the college major choice decision. Female students in the NLSF are more likely to persist in a STEM major at institutions with higher percentage of STEM graduate students that are female, but there is no effect of this measure on male students. Although this paper cannot estimate a causal effect, it is clear that as the graduate student population in STEM fields becomes more female, so does the undergraduate major population. Evidence on the importance of faculty role models is limited. Results suggest that female students in STEM fields with a higher proportion of female faculty members are less likely to persist in the major field. However, this might be capturing the influence of junior versus senior faculty members, as many of the female faculty members are likely to have a lower rank than their male colleagues. Therefore, departments with a high percentage of female professors likely also have a high percentage of junior faculty members, who may not be as savvy at keeping and attracting students to their major yet.

The results in this paper show that the environment of the institution and the STEM field departments can have strong impacts on the major choice of students showing an interest in a STEM major. The way that students originally sort into different departments and institutions may be a driving force behind the under-representation of women and minorities in STEM field majors at graduation, and their higher rates of attrition from these majors doing college. Further research is needed to examine these sorting patterns, and how the characteristics of different STEM departments within the field may have different impacts on the decision to persist in the major. Colleges, 
universities, and others interested in increasing persistence of students in STEM field majors during college should put some focus on the institutional environment, as it seems that students are more likely to continue in a STEM major when there is more of a focus on the undergraduate student experience. 


\section{References}

Ashworth, John, and J. Lynne Evans. (2001). "Modeling student subject choice at secondary and tertiary level: A cross-section study.” Journal of Economic Education, 32(4) pp. 311-22.

Bettinger, Eric P., and Bridget Terry Long. (2005). "Do Faculty Serve as Role Models? The Impact of Instructor Gender on Female Students." American Economic Review, 95(2): 152-157.

Canes, Brandice, and Harvey Rosen. (1995). "Following in her footsteps? Faculty gender composition and women's choices of college majors.” Industrial and Labor Relations Review, 48(3), pp. 486-504.

Carell, Scott, M. Page, and J. West. 2010. "Sex and Science: How Professor Gender Perpetuates the Gender Gap." Quarterly Journal of Economics, 125(3).

Chen, Xianglei, and Thomas Weko. (2009). "Students who study science, technology, engineering and mathematics (STEM) in post-secondary education.” NCES 2009161. Washington, D.C.: U.S. Department of Education, National Center for Education Statistics.

Huang, Gary, Taddeuse Nebiyu, Walter, Elizabeth, and Samuel S. Peng. (2000). "Entry and persistence of women and minorities in college science and engineering education.” NCES 2000-601. Washington, D.C.: National Center for Education Statistics.

National Academy of Science, Committee on Science, Engineering, and Public Policy (COSEPUP). (2005). Rising above the gathering storm: Energizing and employing America for a brighter economic future. Washington, D.C.: National Academies Press.

National Science Board (NSB). (2007). A National Action Plan for Addressing the Critical Needs of the U.S. Science,Technology, Engineering, and Mathematics Education System Arlington, VA: National Science Foundation.

Qian, Y., Basit Zafar, and Hui Xie (2010), "Do Female Faculty Influence Female Students' Choice of College Major, and Why?" Northwestern University Working Paper.

Rask, Kevin N., and Elizabeth M. Bailey. (2002). “Are faculty role models? Evidence from major choice in an undergraduate institution.” Journal of Economic Education, 33(2), pp. 99-124. 
Rask, Kevin N., and Jill Tiefenthaler. (2008). “ The Role of Grade Sensitivity in Explaining the Gender Imbalance in Undergraduate Economics” The Economics of Education Review, 27(6), pp. 676-87.

Robst, J., Keil, J., and D. Russo. (1998). “The effect of faculty gender composition on student retention.” The Economics of Education Review, 17, pp.429-39. 
Table 1: Student descriptive statistics for the NLSF and NELS:88 datasets Panel A: By planned major field

\begin{tabular}{l} 
Female \\
Minority \\
High School GPA \\
Private High School \\
SAT \\
Number of STEM APs \\
Total number of APs \\
\hline $\mathrm{N}$ \\
Panel B: By gender and race
\end{tabular}

\begin{tabular}{|c|c|c|c|c|c|}
\hline \multicolumn{3}{|c|}{ NLSF } & \multicolumn{3}{|c|}{ NELS:88 } \\
\hline STEM & & $\begin{array}{l}\text { Non- } \\
\text { STEM }\end{array}$ & STEM & & $\begin{array}{l}\text { Non- } \\
\text { STEM }\end{array}$ \\
\hline 0.510 & $\star \star \star$ & 0.604 & 0.326 & $\star * \star$ & 0.612 \\
\hline 0.276 & & 0.265 & 0.148 & & 0.156 \\
\hline 3.748 & $\star \star \star ~$ & 3.686 & 3.265 & 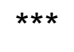 & 3.110 \\
\hline$(0.310)$ & & (0.336) & (0.581) & & $(0.560)$ \\
\hline 0.242 & $* \star *$ & 0.304 & 0.216 & & 0.233 \\
\hline 1302 & & 1304 & 1133 & $* \star *$ & 1058 \\
\hline (170) & & (158) & (178) & & (177) \\
\hline 1.635 & $* * *$ & 1.279 & 0.927 & & 1.051 \\
\hline (1.298) & & (1.203) & (2.601) & & (2.839) \\
\hline 3.406 & & 3.352 & 2.744 & * & 3.257 \\
\hline (2.218) & & (2.165) & (8.039) & & (8.810) \\
\hline 957 & & 2967 & 1030 & & 3520 \\
\hline
\end{tabular}

\begin{tabular}{|c|c|c|c|c|c|c|c|c|c|c|c|c|}
\hline & \multicolumn{6}{|c|}{ NLSF } & \multicolumn{6}{|c|}{ NELS:88 } \\
\hline & Women & & Men & Minority & & $\begin{array}{c}\text { Non- } \\
\text { Minority }\end{array}$ & Women & & Men & Minority & & $\begin{array}{c}\text { Non- } \\
\text { Minority }\end{array}$ \\
\hline Plan Major STEM & 0.214 & $\star * *$ & 0.285 & 0.251 & & 0.241 & 0.135 & $\star \star * *$ & 0.337 & 0.216 & & 0.228 \\
\hline STEM Initiative & 0.325 & $\star \star \star$ & 0.431 & 0.342 & $\star *$ & 0.379 & 0.383 & $\star \star * *$ & 0.566 & 0.472 & & 0.465 \\
\hline Persist in STEM 2nd year & 0.494 & $\star \star \star$ & 0.554 & 0.481 & & 0.540 & & & & & & \\
\hline Persist in STEM to degree & 0.365 & $\star * *$ & 0.431 & 0.307 & ** & 0.431 & 0.435 & & 0.470 & 0.316 & $\star \star \star *$ & 0.483 \\
\hline Switch to STEM by 2 nd year & 0.099 & $\star \star *$ & 0.151 & 0.080 & $\star \star * \star$ & 0.133 & & $\star \star * *$ & 0.127 & 0.078 & * & 0.104 \\
\hline
\end{tabular}




\begin{tabular}{|c|c|c|c|c|c|c|}
\hline & \multicolumn{3}{|c|}{ NLSF } & \multicolumn{3}{|c|}{ NELS:88 } \\
\hline & Persist 2nd year & & Do not persist & Persist STEM degree & & Do not persist \\
\hline Female & 0.481 & * & 0.542 & 0.309 & & 0.341 \\
\hline Minority & 0.253 & * & 0.300 & 0.102 & $* * *$ & 0.186 \\
\hline \multirow[t]{2}{*}{ High School GPA } & 3.761 & & 3.733 & 3.481 & 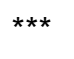 & 3.097 \\
\hline & $(0.316)$ & & $(0.302)$ & $(0.457)$ & & $(0.611)$ \\
\hline Private High School & 0.246 & & 0.239 & 0.210 & & 0.221 \\
\hline \multirow[t]{2}{*}{ SAT } & 1320 & $* \star \star$ & 1276 & 1188 & $* * *$ & 1083 \\
\hline & $(160)$ & & $(180)$ & $(163)$ & & (175) \\
\hline \multirow[t]{2}{*}{ Number of STEM APs } & 1.778 & $* * \star$ & 1.478 & 0.824 & & 1.014 \\
\hline & $(1.304)$ & & $(1.275)$ & (2.388) & & $(2.767)$ \\
\hline \multirow[t]{2}{*}{ Total number of APs } & 3.565 & ** & 3.232 & 2.320 & & 3.102 \\
\hline & (2.168) & & $(2.263)$ & (7.323) & & $(8.589)$ \\
\hline \multirow[t]{2}{*}{ Ratio 1st year STEM GPA to all GPA } & 0.931 & *** & 0.786 & 0.915 & 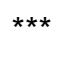 & 0.772 \\
\hline & $(0.171)$ & & $(0.335)$ & $(0.281)$ & & $(0.458)$ \\
\hline
\end{tabular}


Table 3: Descriptive statistics for institutions attended by students in the NLSF and NELS:88 samples

Ratio UG to Grad Enrollment

NLSF NELS:88

No graduate students

$2.606 \quad 13.270$

(2.924)

(51.738)

0.250

0.338

\% Female Faculty in STEM

0.244

0.194

Research Exp/Educ. Exp.

0.235

0.065

$\%$ STEM BAs Female

0.522

0.357

\% STEM BAs Female/\% BAs Female

0.892

0.668

$\%$ STEM BAs Minority

0.113

0.100

$\%$ STEM BAs Minority/\% BAs Minority

0.827

0.791

$\%$ STEM PHDs Female

0.374

0.076

$\%$ STEM PHDs Minority

0.058

0.009

N 28 1070

Note: $\mathrm{PhD}$ percentages are reported for institutions with graduate programs 
Table 4: Average marginal effects from logit estimations of Persistence in STEM field major to sophomore or senior year for NLSF sample, by gender and race.

\begin{tabular}{|c|c|c|c|c|c|c|c|c|}
\hline & \multicolumn{2}{|c|}{ Women } & \multicolumn{2}{|l|}{ Men } & \multicolumn{2}{|c|}{ Minority } & \multicolumn{2}{|c|}{ Non-Minority } \\
\hline & Sophomore & Senior & Sophomore & Senior & Sophomore & Senior & Sophomore & Senior \\
\hline Minority & $\begin{array}{r}0.022 \\
{[0.045]}\end{array}$ & $\begin{array}{r}0.075 \\
{[0.047]}\end{array}$ & $\begin{array}{l}0.108^{\star \star} \\
{[0.046]}\end{array}$ & $\begin{array}{r}-0.071 \\
{[0.048]}\end{array}$ & & & & \\
\hline Female & & & & & $\begin{array}{r}-0.043 \\
{[0.050]}\end{array}$ & $\begin{array}{r}0.047 \\
{[0.053]}\end{array}$ & $\begin{array}{r}0 \\
{[0.030]}\end{array}$ & $\begin{array}{r}-0.031 \\
{[0.029]}\end{array}$ \\
\hline Number of STEM APs & $\begin{array}{l}0.047^{*} \\
{[0.026]}\end{array}$ & $\begin{array}{r}0.019 \\
{[0.025]}\end{array}$ & $\begin{array}{r}0.022 \\
{[0.022]}\end{array}$ & $\begin{array}{c}0.041^{*} \\
{[0.021]}\end{array}$ & $\begin{array}{r}0.101^{\star * *} \\
{[0.036]}\end{array}$ & $\begin{array}{r}0.136^{\star \star \star} \\
{[0.031]}\end{array}$ & $\begin{array}{r}0.015 \\
{[0.018]}\end{array}$ & $\begin{array}{r}0.014 \\
{[0.018]}\end{array}$ \\
\hline $\begin{array}{l}\text { Ratio 1st year STEM GPA to all } \\
\text { GPA }\end{array}$ & $\begin{array}{r}0.386^{* * *} \\
{[0.081]}\end{array}$ & $\begin{array}{r}0.264^{\star * *} \\
{[0.088]}\end{array}$ & $\begin{array}{r}0.547^{\star * *} \\
{[0.095]}\end{array}$ & $\begin{array}{r}0.444^{\star * *} \\
{[0.096]}\end{array}$ & $\begin{array}{r}0.364^{\star * *} \\
{[0.085]}\end{array}$ & $\begin{array}{c}0.170^{*} \\
{[0.100]}\end{array}$ & $\begin{array}{r}0.558^{\star * *} \\
{[0.089]}\end{array}$ & $\begin{array}{r}0.446^{\star \star *} \\
{[0.088]}\end{array}$ \\
\hline Ratio UG to Grad Enrollment & $\begin{array}{r}0.040^{* \star \star} \\
{[0.010]}\end{array}$ & $\begin{array}{r}0.009 \\
{[0.010]}\end{array}$ & $\begin{array}{r}0.035^{\star \star \star} \\
{[0.009]}\end{array}$ & $\begin{array}{l}0.022^{\star *} \\
{[0.009]}\end{array}$ & $\begin{array}{l}0.030^{* *} \\
{[0.015]}\end{array}$ & $\begin{array}{r}-0.022 \\
{[0.015]}\end{array}$ & $\begin{array}{r}0.037^{\star \star \star} \\
{[0.007]}\end{array}$ & $\begin{array}{r}0.030^{* \star *} \\
{[0.007]}\end{array}$ \\
\hline No graduate students & $\begin{array}{l}0.327^{\star *} \\
{[0.140]}\end{array}$ & $\begin{array}{r}-0.011 \\
{[0.178]}\end{array}$ & $\begin{array}{l}0.242^{\star *} \\
{[0.106]}\end{array}$ & $\begin{array}{r}-0.009 \\
{[0.139]}\end{array}$ & & & $\begin{array}{l}0.213^{\star *} \\
{[0.095]}\end{array}$ & $\begin{array}{r}-0.093 \\
{[0.102]}\end{array}$ \\
\hline \% Female Faculty in STEM & $\begin{array}{r}-1.682^{\star \star \star} \\
{[0.594]}\end{array}$ & $\begin{array}{r}0.336 \\
{[0.595]}\end{array}$ & $\begin{array}{r}-1.854^{\star \star} \\
{[0.732]}\end{array}$ & $\begin{array}{r}-0.844 \\
{[0.760]}\end{array}$ & $\begin{array}{r}0.356 \\
{[1.099]}\end{array}$ & $\begin{array}{r}0.782 \\
{[1.078]}\end{array}$ & $\begin{array}{r}-1.388^{\star \star \star} \\
{[0.530]}\end{array}$ & $\begin{array}{r}-0.518 \\
{[0.534]}\end{array}$ \\
\hline Research Exp/Educ. Exp. & $\begin{array}{r}-0.18 \\
{[0.158]}\end{array}$ & $\begin{array}{r}-0.169 \\
{[0.157]}\end{array}$ & $\begin{array}{r}-0.429^{\star \star *} \\
{[0.143]}\end{array}$ & $\begin{array}{r}0.025 \\
{[0.144]}\end{array}$ & $\begin{array}{r}-0.417^{\star *} \\
{[0.189]}\end{array}$ & $\begin{array}{r}0.073 \\
{[0.201]}\end{array}$ & $\begin{array}{l}-0.195^{*} \\
{[0.115]}\end{array}$ & $\begin{array}{r}0.081 \\
{[0.115]}\end{array}$ \\
\hline $\begin{array}{l}\% \text { STEM BAs Female/\% Total } \\
\text { BAs Female }\end{array}$ & $\begin{array}{r}-0.708 \\
{[0.677]}\end{array}$ & $\begin{array}{r}-1.591^{\star \star} \\
{[0.676]}\end{array}$ & $\begin{array}{r}-0.312 \\
{[0.584]}\end{array}$ & $\begin{array}{r}0.585 \\
{[0.589]}\end{array}$ & & & & \\
\hline $\begin{array}{l}\% \text { STEM BAs Minority } / \% \text { Total } \\
\text { BAs Minority }\end{array}$ & & & & & $\begin{array}{l}-0.134 \\
{[0.342]}\end{array}$ & $\begin{array}{r}-0.595 \\
{[0.366]}\end{array}$ & $\begin{array}{r}0.247 \\
{[0.196]}\end{array}$ & $\begin{array}{r}0.379^{\star} \\
{[0.196]}\end{array}$ \\
\hline \% STEM PHDs Female & $\begin{array}{c}0.736^{*} \\
{[0.378]}\end{array}$ & $\begin{array}{r}0.055 \\
{[0.375]}\end{array}$ & $\begin{array}{r}0.398 \\
{[0.319]}\end{array}$ & $\begin{array}{l}-0.409 \\
{[0.316]}\end{array}$ & & & & \\
\hline \% STEM PHDs Minority & & & & & $\begin{array}{r}0.244 \\
{[0.218]}\end{array}$ & $\begin{array}{r}0.119 \\
{[0.226]}\end{array}$ & $\begin{array}{r}1.088 \\
{[0.904]}\end{array}$ & $\begin{array}{r}-0.95 \\
{[0.908]}\end{array}$ \\
\hline Observations & 450 & 450 & 450 & 450 & 250 & 250 & 650 & 650 \\
\hline
\end{tabular}


Table 5: Average marginal effects from logit estimations of persistence to degree in STEM field major for NELS:88 sample, by gender and race

\begin{tabular}{|c|c|c|c|c|}
\hline Minority & $\begin{array}{l}-0.0130 \\
{[0.0643]}\end{array}$ & $\begin{array}{l}-0.0248 \\
{[0.0529]}\end{array}$ & & \\
\hline Female & & & $\begin{array}{l}-0.0485 \\
{[0.0762]}\end{array}$ & $\begin{array}{l}-0.0489 \\
{[0.0298]}\end{array}$ \\
\hline Number of STEM APs & $\begin{array}{c}0.130 \\
{[0.0961]}\end{array}$ & $\begin{array}{c}0.0684 \\
{[0.0599]}\end{array}$ & $\begin{array}{l}0.0127 \\
{[0.428]}\end{array}$ & $\begin{array}{l}0.0872^{\star} \\
{[0.0518]}\end{array}$ \\
\hline Ratio 1st year STEM GPA to all GPA & $\begin{array}{l}0.208^{\star * *} \\
{[0.0620]}\end{array}$ & $\begin{array}{l}0.183^{\star * \star} \\
{[0.0446]}\end{array}$ & $\begin{array}{c}0.194^{\star *} \\
{[0.0926]} \\
-5.19 \mathrm{e}-\end{array}$ & $\begin{array}{l}0.181^{* * *} \\
{[0.0398]}\end{array}$ \\
\hline Ratio UG to Grad Enrollment & $\begin{array}{c}0.00113 \\
{[0.00161]}\end{array}$ & $\begin{array}{l}-0.000963 \\
{[0.000864]}\end{array}$ & $\begin{array}{c}05 \\
{[0.00297]}\end{array}$ & $\begin{array}{c}5.92 \mathrm{e}-05 \\
{[0.000742]}\end{array}$ \\
\hline No graduate students & $\begin{array}{c}0.0149 \\
{[0.0870]}\end{array}$ & $\begin{array}{l}-0.123^{\star \star} \\
{[0.0587]}\end{array}$ & $\begin{array}{l}0.0324 \\
{[0.139]}\end{array}$ & $\begin{array}{l}-0.0299 \\
{[0.0512]}\end{array}$ \\
\hline \% Female Faculty in STEM & $\begin{array}{l}-0.183 \\
{[0.217]}\end{array}$ & $\begin{array}{l}0.0427 \\
{[0.191]}\end{array}$ & $\begin{array}{c}0.129 \\
{[0.404]}\end{array}$ & $\begin{array}{l}-0.176 \\
{[0.153]}\end{array}$ \\
\hline Research Exp/Educ. Exp. & $\begin{array}{l}0.322^{\star \star *} \\
{[0.122]}\end{array}$ & $\begin{array}{l}0.310 * * \star \\
{[0.0971]}\end{array}$ & $\begin{array}{l}0.0727 \\
{[0.191]}\end{array}$ & $\begin{array}{l}0.245^{\star \star \star} \\
{[0.0796]}\end{array}$ \\
\hline $\begin{array}{l}\% \text { STEM BAs Female } / \% \text { Total BAs } \\
\text { Female }\end{array}$ & $\begin{array}{c}0.135 \\
{[0.138]}\end{array}$ & $\begin{array}{c}0.0508 \\
{[0.0912]}\end{array}$ & & \\
\hline $\begin{array}{l}\% \text { STEM BAs Minorityl\% Total BAs } \\
\text { Minority }\end{array}$ & & & $\begin{array}{c}0.00809 \\
{[0.186]}\end{array}$ & $\begin{array}{l}-0.0152 \\
{[0.0349]}\end{array}$ \\
\hline \% STEM PHDs Female & $\begin{array}{l}-0.236 \\
{[0.201]}\end{array}$ & $\begin{array}{c}-0.526^{\star \star \star} \\
{[0.194]}\end{array}$ & & \\
\hline \% STEM PHDs Minority & & & $\begin{array}{r}-0.0400 \\
{[0.512]}\end{array}$ & $\begin{array}{l}0.0556 \\
{[0.873]}\end{array}$ \\
\hline Observations & 320 & 660 & 140 & 840 \\
\hline
\end{tabular}


Table 6: Average marginal effects from logit estimations of the probability of switching to a STEM field major by sophomore year for NLSF sample and by senior year for NELS:88, by gender and race

\begin{tabular}{|c|c|c|c|c|c|c|c|c|}
\hline & \multicolumn{4}{|c|}{ NLSF } & \multicolumn{4}{|c|}{ NELS:88 } \\
\hline & Women & Men & Minority & $\begin{array}{c}\text { Non- } \\
\text { Minority }\end{array}$ & Women & Men & Minority & $\begin{array}{c}\text { Non- } \\
\text { Minority }\end{array}$ \\
\hline Minority & $\begin{array}{r}0.002 \\
{[0.019]}\end{array}$ & $\begin{array}{c}-0.027 \\
{[0.024]}\end{array}$ & & & $\begin{array}{c}-0.000658 \\
{[0.0189]}\end{array}$ & $\begin{array}{l}-0.0256 \\
{[0.0265]}\end{array}$ & & \\
\hline Female & & & $\begin{array}{c}-0.007 \\
{[0.026]}\end{array}$ & $\begin{array}{r}-0.037^{\star * *} \\
{[0.012]}\end{array}$ & & & $\begin{array}{c}-0.0522^{\star *} \\
{[0.0250]}\end{array}$ & $\begin{array}{c}-0.0478^{\star \star *} \\
{[0.0100]}\end{array}$ \\
\hline Number of STEM APs & $\begin{array}{r}0.048^{\star \star *} \\
{[0.010]}\end{array}$ & $\begin{array}{c}0.027^{* *} \\
{[0.011]}\end{array}$ & $\begin{array}{r}0.021 \\
{[0.015]}\end{array}$ & $\begin{array}{r}0.046^{\star \star *} \\
{[0.008]}\end{array}$ & $\begin{array}{c}0.0768^{\star \star \star} \\
{[0.0282]}\end{array}$ & $\begin{array}{c}0.0588 \\
{[0.0361]}\end{array}$ & $\begin{array}{l}0.282^{\star \star} \\
{[0.132]}\end{array}$ & $\begin{array}{c}0.0646 * \star * \\
{[0.0226]}\end{array}$ \\
\hline Ratio 1st year STEM GPA to all GPA & $\begin{array}{r}0.112^{\star * *} \\
{[0.026]}\end{array}$ & $\begin{array}{r}0.154^{\star * *} \\
{[0.033]}\end{array}$ & $\begin{array}{r}0.135^{\star * *} \\
{[0.043]}\end{array}$ & $\begin{array}{r}0.129 * * * \\
{[0.024]}\end{array}$ & $\begin{array}{c}0.0609 * \star \star \\
{[0.0144]}\end{array}$ & $\begin{array}{c}0.0901^{\star \star \star} \\
{[0.0233]}\end{array}$ & $\begin{array}{c}0.0676^{\star * * *} \\
{[0.0250]}\end{array}$ & $\begin{array}{c}0.0797^{* * *} \\
{[0.0149]}\end{array}$ \\
\hline Ratio UG to Grad Enrollment & $\begin{array}{r}0.004 \\
{[0.004]}\end{array}$ & $\begin{array}{r}0.004 \\
{[0.005]}\end{array}$ & $\begin{array}{r}-0.001 \\
{[0.007]}\end{array}$ & $\begin{array}{r}0.010^{\star \star \star} \\
{[0.003]}\end{array}$ & $\begin{array}{c}9.77 \mathrm{e}-05 \\
{[0.000184]}\end{array}$ & $\begin{array}{c}-0.000174 \\
{[0.000411]}\end{array}$ & $\begin{array}{c}0.00136^{*} \\
{[0.000788]}\end{array}$ & $\begin{array}{c}5.71 \mathrm{e}-06 \\
{[0.000191]}\end{array}$ \\
\hline No graduate students & $\begin{array}{r}0.076 \\
{[0.066]}\end{array}$ & $\begin{array}{r}0.093 \\
{[0.071]}\end{array}$ & $\begin{array}{r}0.009 \\
{[0.068]}\end{array}$ & $\begin{array}{r}0.01 \\
{[0.041]}\end{array}$ & $\begin{array}{l}-0.00244 \\
{[0.0195]}\end{array}$ & $\begin{array}{c}0.0109 \\
{[0.0349]}\end{array}$ & $\begin{array}{c}0.0728 \\
{[0.0653]}\end{array}$ & $\begin{array}{c}0.0141 \\
{[0.0199]}\end{array}$ \\
\hline \% Female Faculty in STEM & $\begin{array}{r}-0.09 \\
{[0.236]}\end{array}$ & $\begin{array}{r}-0.042 \\
{[0.369]}\end{array}$ & $\begin{array}{r}0.42 \\
{[0.394]}\end{array}$ & $\begin{array}{r}-0.289 \\
{[0.242]}\end{array}$ & $\begin{array}{c}-0.0256 \\
{[0.0583]}\end{array}$ & $\begin{array}{l}-0.0620 \\
{[0.0995]}\end{array}$ & $\begin{array}{l}-0.201 \\
{[0.137]}\end{array}$ & $\begin{array}{l}-0.0183 \\
{[0.0583]}\end{array}$ \\
\hline Research Exp/Educ. Exp. & $\begin{array}{r}0.057 \\
{[0.064]}\end{array}$ & $\begin{array}{r}-0.199^{\star *} \\
{[0.078]}\end{array}$ & $\begin{array}{r}0.121 \\
{[0.104]}\end{array}$ & $\begin{array}{c}-0.002 \\
{[0.053]}\end{array}$ & $\begin{array}{c}0.0421 \\
{[0.0410]}\end{array}$ & $\begin{array}{c}0.134^{\star \star} \\
{[0.0548]}\end{array}$ & $\begin{array}{c}0.122^{*} \\
{[0.0691]}\end{array}$ & $\begin{array}{c}0.0498 \\
{[0.0345]}\end{array}$ \\
\hline$\%$ STEM BAs Female/\% Total BAs Female & $\begin{array}{r}0.831^{\star \star \star} \\
{[0.239]}\end{array}$ & $\begin{array}{l}-0.520^{*} \\
{[0.308]}\end{array}$ & & & $\begin{array}{l}0.0638^{\star} \\
{[0.0364]}\end{array}$ & $\begin{array}{c}0.0597 \\
{[0.0567]}\end{array}$ & & \\
\hline \% STEM BAs Minority/\% Total BAs Minority & & & $\begin{array}{r}0.228 \\
{[0.180]}\end{array}$ & $\begin{array}{r}0.106 \\
{[0.090]}\end{array}$ & & & $\begin{array}{c}0.104^{\star *} \\
{[0.0460]}\end{array}$ & $\begin{array}{c}-0.000298 \\
{[0.00901]}\end{array}$ \\
\hline \% STEM PHDs Female & $\begin{array}{r}0.482^{\star \star \star} \\
{[0.129]}\end{array}$ & $\begin{array}{r}-0.09 \\
{[0.164]}\end{array}$ & & & $\begin{array}{l}-0.0476 \\
{[0.0562]}\end{array}$ & $\begin{array}{l}-0.0749 \\
{[0.0932]}\end{array}$ & & \\
\hline \% STEM PHDs Minority & & & $\begin{array}{c}-0.037 \\
{[0.161]}\end{array}$ & $\begin{array}{l}-0.789^{*} \\
{[0.415]}\end{array}$ & & & $\begin{array}{c}0.199 \\
{[0.165]}\end{array}$ & $\begin{array}{l}-0.0278 \\
{[0.300]} \\
\end{array}$ \\
\hline Observations & 1560 & 1070 & 700 & 1920 & 2060 & 1300 & 530 & 2840 \\
\hline
\end{tabular}


